\author{
O. I. Kalchenko, M. O. Vysotsky, S. O. Cherenok
}

Institute of Organic Chemistry of the National Academy of Sciences of Ukraine, Ukraine

5, Murmanska str., Kyiv, 02094, Ukraine.E-mail: oik@ioch.kiev.ua

\title{
Phosphorylated calix[4,8]arenes improve the RP HPLC separation of benzene derivatives
}

Aim. To study the effect of 5,11,17,23-tetrakis(diisopropoxyphosphonyl)-25,26,27,28-tetrapropoxycalix[4]arene and octakis(diethoxyphosphoryloxy)-tert-butylcalix[8]arene additives to the MeCN- $\mathrm{H}_{2} \mathrm{O}$ mobile phase (86:14) on the selectivity of the separation of aromatic compounds by the reversed-phase high performance liquid chromatography (RP HPLC) using a Separon SGX C18 support.

Results and discussion. The process of complexation of phosphorylated calix[4,8]arenes with benzene derivatives in the mobile phase plays a key role in the RP HPLC separation of analytes. The stability constants of the inclusion complexes and the chromatographic separation coefficients of the analytes depend on the nature of the aromatic compounds and the cavity size of the calixarene macrocycle.

Experimental part. The HPLC analysis was performed in acetonitrile-water (86:14) solution using a Separon SGX C18 column. The stability constants of the calixarene complexes were determined using the dependence of $1 / k^{\prime}$ chromatographic parameters of benzene derivatives on the calixarene concentration in the mobile phase. Molecular modelling of the calixarene complexes was carried out using a Hyper Chem 8.0 program.

Conclusions. The phosphorus-contained calixarenes due to their ability to form supramolecular complexes with aromatic molecules can be used as additives to the RP HPLC mobile phase and improve separation of benzene derivatives.

Key words: calixarenes; benzene derivatives; inclusion complexes; stability constants; separation selectivity; RP HPLC; molecular modelling

О. І. Кальченко, М. О. Висоцький, С. О. Черенок

Інститут органічної хімії НАН України, Україна

Фосфорильовані калікс[4,8]арени покращують ОФ ВЕРХ розділення

похідних бензену

Мета. Дослідити вплив добавок 5,11,17,23-тетракіс(діізопропоксифосфоніл)-25,26,27,28-тетрапропоксикалікс[4]арену і октакіс(діетоксифосфорилокси)-mpem-бутилкалікс[8]арену до рухомої фрази складу $\mathrm{MeCN}_{-} \mathrm{H}_{2} \mathrm{O}$ (86:14) на селективність розділення ароматичних сполук методом обернено-фазної високоефективної рідинної хроматографії (ОФ ВЕРX) з використанням насадки Separon SGX C18.

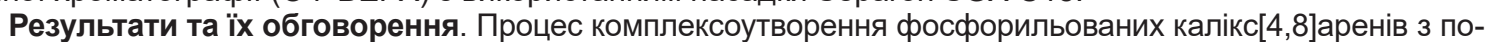
хідними бензену у мобільній фазі відіграє ключову роль у ОФ ВЕРХ розділенні цих аналітів. Константи стійкості комплексів включення та коефіцієнти хроматографрічного розділення аналітів залежать від природи ароматичних сполук та розміру порожнини каліксаренового макроциклу.

Експериментальна частина. ОФ ВЕРХ аналіз проводили у розчині ацетонітрил-вода (86:14) 3 використанням колонки з насадкою Separon SGX C18. Константи стійкості каліксаренових комплексів визначали із залежності хроматографрічних параметрів 1/k' похідних бензену від концентрації каліксарену в рухомій фразі. Молекулярне моделювання комплексів каліксаренів виконано за програмою Hyper Chem, версія 8.0.

Висновки. Добавки фоссфоровмісних калікс[4,8]аренів до рухомої фрази завдяки здатності утворювати комплекси включення з ароматичними молекулами покращують їх ОФ ВЕРХ розділення на насадці Separon SGX C18.

Ключові слова: каліксарени; похідні бензену; комплекси включення; константи стійкості; селективність розділення; ОФ ВЕРХ; молекулярне моделювання

Copyright $\odot 2020$, O. I. Kalchenko, M. O. Vysotsky, S. O. Cherenok This is an open access article under the CC BY license (http://creativecommons.org/licenses/by/4.0)

Calix $[n]$ arenes - macrocyclic oligomers consisting of phenolic units linked by methylene spacers are well known complexants that separate different molecules in solutions [1-9]. These compounds form supramolecular complexes with analyte molecules; they have been applied for the design of stationary chromatographic phases [10-16], and as additives to mobile phases [17] that improve the HPLC separation of organic or inorganic analytes. In this paper we report the effect of the additives of 5,11,17,23-tetrakis(diisopropoxyphosphonyl)-25,26,27,28-tetrapropoxy- calix[4]arene $\mathbf{1}$ and octakis(diethoxyphosphoryloxy)tert-butylcalix[8]arene 2 to the acetonitrile-water mobile phase on the selectivity of the HPLC separation of some benzene derivatives. The calixarene additives improve the separation due to the formation of the host-guest inclusion complexes. The linear character of the plots of $1 / k^{\prime} v s$ the calixarene concentration in the mobile phase allows calculating the stability constants $K_{A}$ of the complexes. The correlations of the separation selectivity induced by the calixarene additives with a ratio of the stability constants of 


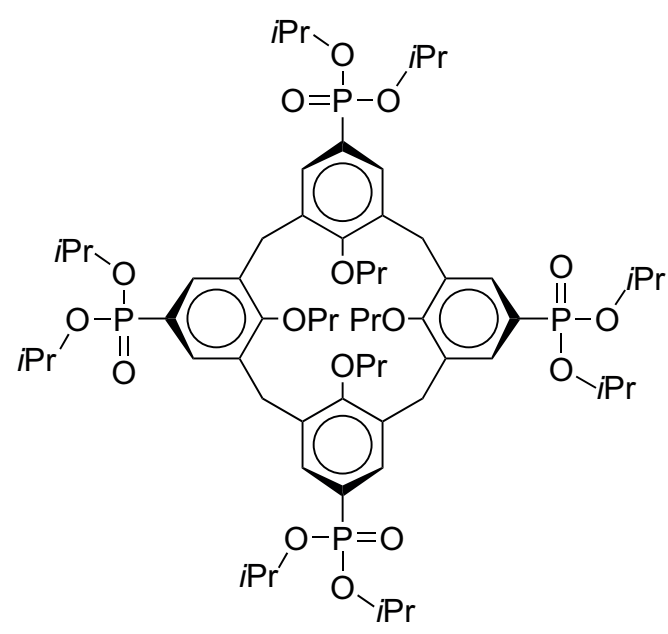

1

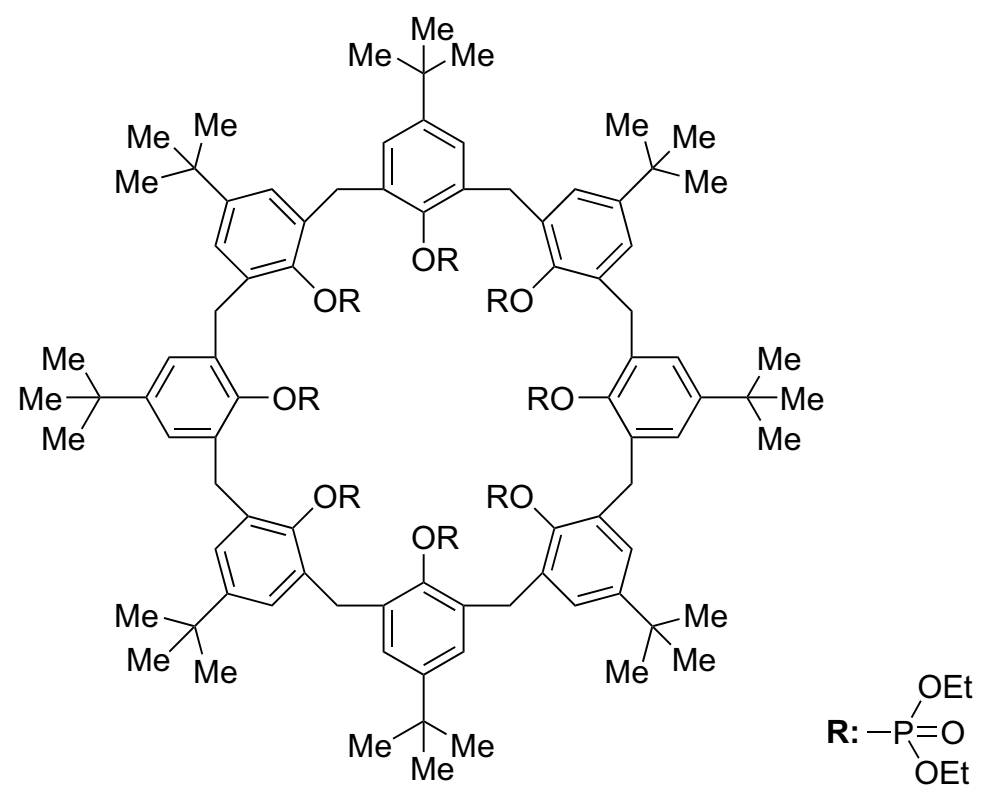

Fig. 1. Tetrakis(diisopropoxyphosphonyl)tetrapropoxycalix[4]arene 1 and octakis(diethoxyphosphoryloxy)-tert-butylcalix[8]arene 2

the host-guest inclusion complexes of benzene derivatives were found. The complexation is influenced by $\log P$, the volume and other parameters of analytes (Fig. 1).

\section{Results and discussion}

Complexation of calix[4]arene $\mathbf{1}$ and calix[8]arene 2 with benzene derivatives was studied by the RP HPLC method described in papers $[18,19]$. Calix [4]arene $\mathbf{1}$ and calix[8]arene $\mathbf{2}$ were characterized by linear adsorption isotherms (Fig. 2, 3) that indicated their reversible adsorption by the column surface. Due to these characteristics, calix[4,8]arenes $\mathbf{1}, \mathbf{2}$ are potential selectors for the RP HPLC separation of analytes.

The calixarene additives to the mobile phase decrease the capacity coefficient $k^{\prime}$ of benzene derivatives due to the formation of the host-guest inclusion complexes. The linear plots of $1 / k^{\prime} v s$ the calix[4]arene and calix[8]arene concentration (Fig. 4, 5) indicate the formation of the host-guest inclusion complexes with stoichiometry in the ratio of $1: 1$. It allows

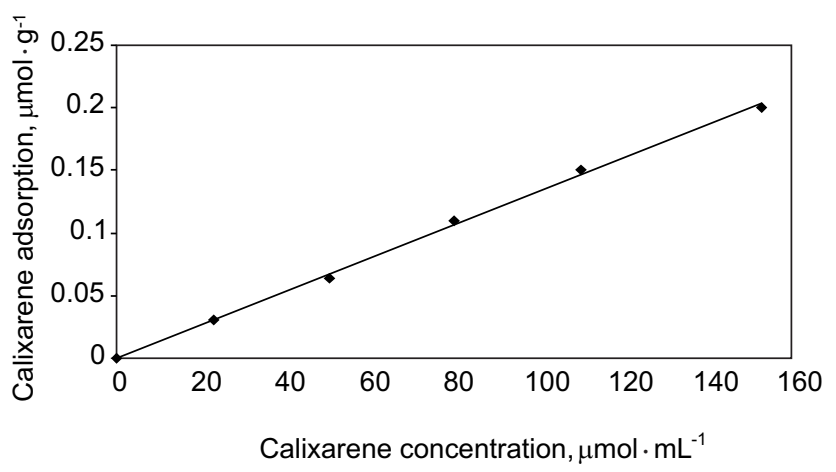

Fig. 2. The adsorption isotherm of tetraphosphorylated calix[4]arene $1\left(R^{2}=0.99\right)$ using the equation (1) for calculation of their stability constants $K_{A}$ :

$$
1 / k^{\prime}=1 / k_{0}^{\prime}+K_{A} \times[\mathrm{CA}] / k_{0}^{\prime},
$$

where: $k_{0}^{\prime}$ ' $k^{\prime}$ are capacity factors of the benzene derivatives determined in the absence and in the presence of calix[4,8]arenes in the mobile phase.

It has been shown that the addition of calixarenes to the mobile phase improves the separation selectivity of benzene analytes (Tables 1,2 ). The separation coefficient $\left(\alpha_{1}\right)$ calculated as the ratio of the retention times of the pair of analytes depends on the size of the macrocyclic skeleton, as well as the nature, quantity and position of the substituent in the molecules of aromatic analytes.

According to the data presented in Table 1, the addition of phosphorylated calix[4]arene $\mathbf{1}$ to the mobile phase increases the analyte separation $\left(\alpha_{1} / \alpha_{0}=1.10-2.05\right)$.

The best separation has been observed for the pairs of analytes, such as $p$-aminophenol vs iodobenzene

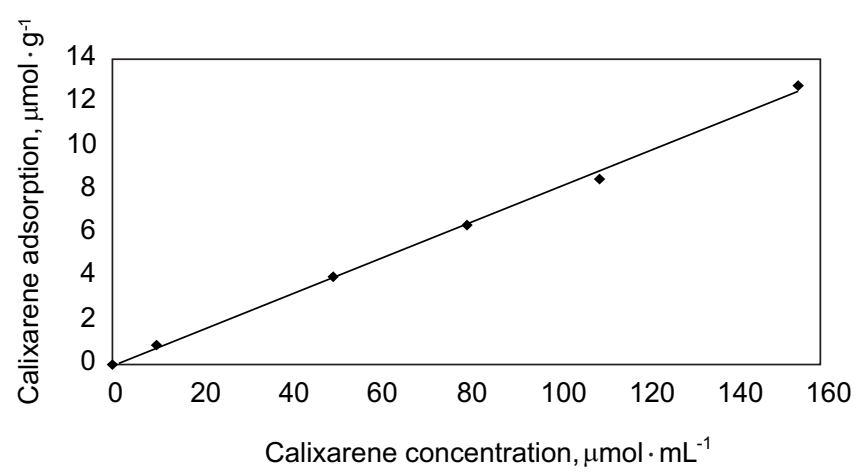

Fig. 3. The adsorption isotherm of octaphosphorylated calix[8]arene $2\left(R^{2}=0.99\right)$ 


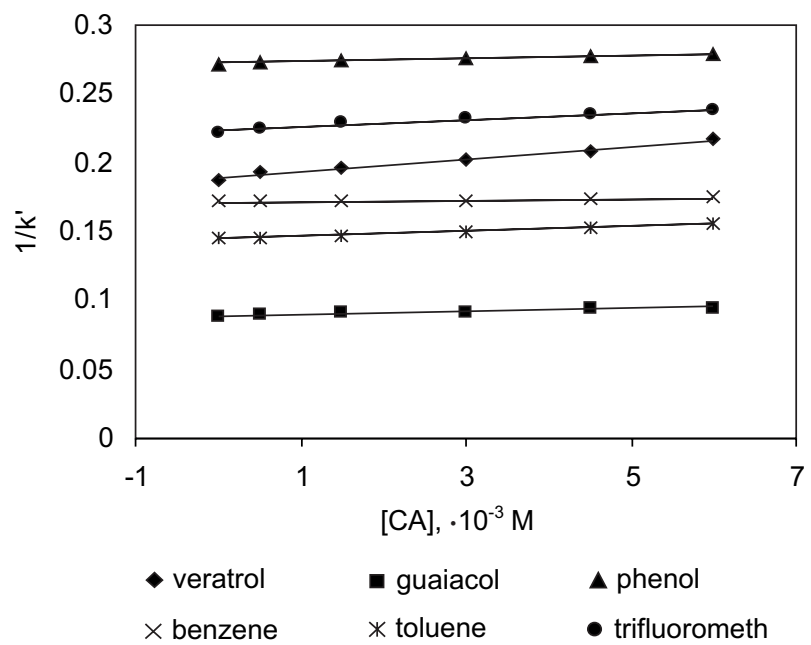

Fig. 4. Plots of $1 / k^{\prime}$ for some benzene derivatives: veratrol, guaiacol, phenol, benzene, toluene and trichloromethylbenzene vs the calix[4]arene 1 concentration in the mobile phase $\left(R^{2}=0.95-0.99\right)$

$\left(\alpha_{1} / \alpha_{0}=1.78\right)$, phenol vs $p$-aminophenol $\left(\alpha_{1} / \alpha_{0}=2.05\right)$, veratrole $v s$ guaiacol $\left(\alpha_{1} / \alpha_{0}=1.42\right), m$-toluidine vs $N, N$-dimethyl- $p$-toluidine $\left(\alpha_{1} / \alpha_{0}=1.42\right)$, and $m$-xylene $v s$ chlorobenzene $\left(\alpha_{1} / \alpha_{0}=1.36\right)$. Other pairs of analytes were separated by calixarene 1 less effectively.

Calix[8]arene 2 additive to the mobile phase also improves the separation selectivity of benzene derivatives $\left(\alpha_{1} / \alpha_{0}=1.06-1.74\right)$. The best separation was observed for the following analytes: resorcinol vs trichloromethylbenzene $\left(\alpha_{1} / \alpha_{0}=1.74\right)$, toluene vs resorcinol $\left(\alpha_{1} / \alpha_{0}=1.71\right)$, toluene vs $p$-methylphenol $\left(\alpha_{1} / \alpha_{0}=1.58\right)$, trichloromethylbenzene vs trifluoromethylbenzene $\left(\alpha_{1} / \alpha_{0}=1.49\right)$ and phenol $v s$ veratrol $\left(\alpha_{1} / \alpha_{0}=1.32\right)$ (Table 2$)$.

The increase in separation selectivity of the analytes after the calixarene addition is explained by the formation of the host-guest inclusion complexes with different adsorption on the stationary phase compared to free analytes. The stability constants $K_{A}$ of the complexes depend on the calixarene structure, as well as on the nature, quantity, position of the substituents in the benzene analytes. The ratio of the separation selectivity $\left(\alpha_{1} / \alpha_{0}\right)$, induced by calixarene additives 1, 2 correlates with the ratio of the stability constants of its complexes $\left(S=K_{1} / K_{2}\right)$ (Fig. 6, 7).

The complexes can be stabilized by hydrogen bonds, $\pi-\pi, \mathrm{C}-\mathrm{H} \cdots \pi$, solvophobic interactions and van der Waals forces between the calixarene and analytes. Fig. 8 illustrates the energy minimized molecular structures of calixarene $\mathbf{1}$ and its complex with $p$-aminophenol.

Calixarene $\mathbf{1}$ functionalized by phosphonyl groups at the upper rim of the macrocycle exists in the coneconformation (Fig. 8a). Complexation with $p$-aminophenol does not change the conformation. For calixarene $\mathbf{1}$ there is the possibility of forming two types of the complexes with $p$-aminophenol. In the comp-

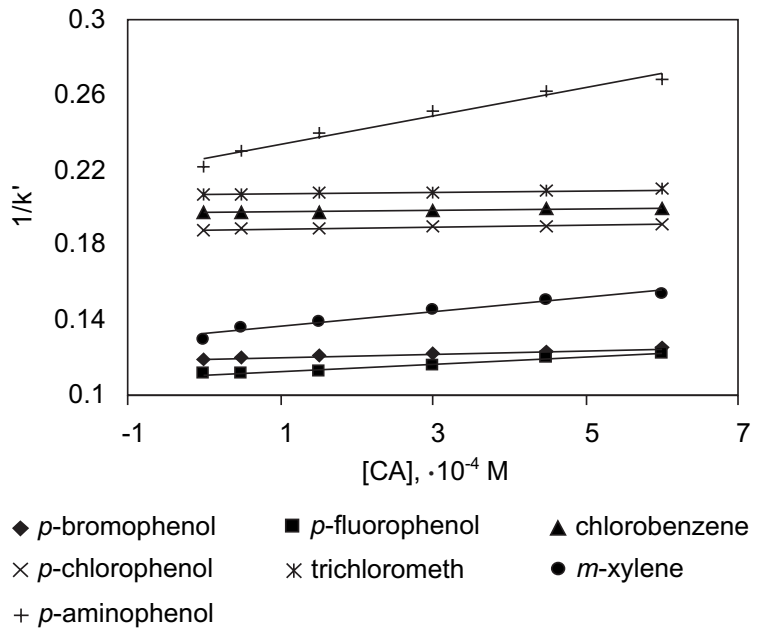

Fig. 5. Plots of $1 / k^{\prime}$ for some benzene derivatives: $p$-bromophenol, $p$-fluorophenol, chlorobenzene, $p$-chlorophenol, trichloromethylbenzene, $m$-xylene and $p$-aminophenol vs the calix[8]arene 2 concentration in the mobile phase $\left(R^{2}=0.95-0.99\right)$

lex b (Fig. 8b), the phenolic group forms the hydrogen bond with an oxygen atom of the phosphonyl group at the upper rim. In the complex c (Fig. 8c), the phenolic group creates the hydrogen bond with an ether oxygen atom at the lower rim.

Octaphosphorylated calix[8]arene 2 (Fig. 9a) that is larger by size with free rotation of the aromatic fragments around $\mathrm{Ar}-\mathrm{CH}_{2}-\mathrm{Ar}$ bonds changes its conformation after complexation with phenol. A phenol molecule is located in the center of the calixarene cavity and forms the hydrogen bond $\mathrm{Ph}-\mathrm{O}-\mathrm{H} \cdots \mathrm{O}(\mathrm{P}=0) \mathrm{Ar}$ with an ether oxygen atom (Fig. 9b).

\section{Experimental part}

The calixarenes were synthesized by the methods described previously: 1 [18] and 2 [19]. Acetonitrile was obtained from the Acros Organics (Thermo Fisher Scientific, New Jersey, USA).

\section{HPLC analysis}

The HPLC analysis was performed using the liquid chromatography system (Hitachi, Ltd., Tokyo, Japan). The column $(250 \times 4.6 \mathrm{~mm}$ i.d. $)$ was packed with Separon SGX C18 (Merck, Darmstadt, Germany). Experiments were performed in isocratic conditions. The acetonitrile-water $(86: 14, v / v)$ mixture was used as the mobile phase. The calixarene concentrations in the mobile phase were $0.05-0.6 \mathrm{mM}$. The UV detector was operated at the wavelength of $254 \mathrm{~nm}$, and the flow rate was $0.8 \mathrm{~mL} / \mathrm{min}$. The samples of the analytes used for injections were dissolved in the same acetonitrilewater $(86: 14, v / v)$ mixture $(c=0.01 \mathrm{mM})$. All chromatograms were obtained at $26^{\circ} \mathrm{C}$. The mobile phase which contained the calixarene additive was equilibrated for $3 \mathrm{~h}$ before the analysis. Under these conditions the chromatographic column was saturated with the calixarene additive. 
The separation selectivity* of the benzene derivatives induced by calix[4]arene 1 additive

\begin{tabular}{|l|c|c|c|c|}
\hline \multicolumn{1}{|c|}{ Analytes separated } & $\begin{array}{c}\text { Selectivity } \\
\text { without } \\
\text { calixarene 1 } \\
\text { additive, } \mathrm{a}_{0}\end{array}$ & $\begin{array}{c}\text { Selectivity } \\
\text { with } \\
\text { calixarene 1 } \\
\text { additive, } \mathrm{a}_{1}\end{array}$ & $\begin{array}{c}\text { Selectivity } \\
\text { ratio, } \mathrm{a}_{1} / \mathrm{a}_{0}\end{array}$ & $\begin{array}{c}\text { Stability } \\
\text { constant ratio, } \\
\mathrm{S}=K_{1} / K_{2}[18]\end{array}$ \\
\hline veratrol vs guaiacol & 1.18 & 1.67 & 1.42 & 2.02 \\
\hline$p$-xylene vs isopropylbenzene & 2.00 & 2.20 & 1.10 & 1.11 \\
\hline guaiacol vs trifluoromethylbenzene & 1.78 & 1.88 & 1.10 & 1.09 \\
\hline$p$-xylene vs benzyl alcohol & 1.82 & 1.98 & 1.10 & 1.39 \\
\hline$p$-cyanophenol vs $p$-aminophenol & 1.20 & 1.44 & 1.20 & 1.06 \\
\hline$m$-xylene vs chlorobenzene & 1.00 & 1.36 & 1.36 & 2.58 \\
\hline$p$-fluorophenol vs trifluoromethylbenzene & 1.00 & 1.11 & 1.11 & 1.03 \\
\hline$m$-toluidine vs $N, N$-dimethyl- $p$-toluidine & 3.65 & 5.20 & 1.42 & 1.88 \\
\hline toluene vs $p$-methoxytoluene & 3.31 & 4.50 & 1.36 & 1.81 \\
\hline phenol vs guaiacol & 1.03 & 1.77 & 1.71 & 4.06 \\
\hline$p$-aminophenol vs iodobenzene & 1.53 & 2.72 & 1.78 & 4.70 \\
\hline phenol vs $m$-nitropenol & 1.68 & 1.86 & 1.11 & 1.22 \\
\hline phenol vs $p$-aminophenol & 1.11 & 2.28 & 2.05 & 10.28 \\
\hline trifluoromethylbenzene vs trichloromethylbenzene & 2.28 & 3.47 & 1.52 & 10.92 \\
\hline
\end{tabular}

Notes: $*$ - the uncertainties of the parameters were $5-7 \%$.

Table 2

The separation selectivity* of the benzene derivatives induced by calix[8]arene $\mathbf{2}$ additive

\begin{tabular}{|l|c|c|c|c|}
\hline \multicolumn{1}{|c|}{ Analytes separated } & $\begin{array}{c}\text { Selectivity without } \\
\text { calixarene 2 } \\
\text { additive, } a_{0}\end{array}$ & $\begin{array}{c}\text { Selectivity with } \\
\text { calixarene 2 } \\
\text { additive, } a_{1}\end{array}$ & $\begin{array}{c}\text { Selectivity } \\
\text { ratio, } a_{1} / a_{0}\end{array}$ & $\begin{array}{c}\text { Stability } \\
\text { constant ratio, } \\
\text { S= } K_{1} / K_{2}[19]\end{array}$ \\
\hline benzene vs phenol & 1.11 & 1.47 & 1.22 & 1.40 \\
\hline phenol vs $p$-chlorophenol & 1.04 & 1.17 & 1.13 & 1.12 \\
\hline phenol vs $p$-methylphenol & 1.04 & 1.06 & 1.02 & 1.18 \\
\hline phenol vs guaiacol & 1.03 & 1.09 & 1.06 & 1.18 \\
\hline phenol vs resorcinol & 1.08 & 1.15 & 1.06 & 1.32 \\
\hline phenol vs veratrol & 1.00 & 1.32 & 1.32 & 1.25 \\
\hline toluene vs resorcinol & 1.12 & 1.91 & 1.71 & 1.22 \\
\hline benzene vs trichloromethylbenzene & 2.55 & 3.41 & 1.34 & 2.43 \\
\hline benzene vs toluene & 1.04 & 1.36 & 1.31 & 1.55 \\
\hline benzene vs resorcinol & 1.08 & 1.40 & 1.30 & 1.89 \\
\hline benzene vs trifluoromethylbenzene & 1.77 & 1.97 & 1.11 & 1.22 \\
\hline trichloromethylbenzene vs trifluoromethylbenzene & 1.29 & 1.92 & 1.49 & 2.96 \\
\hline benzene $v$ g guaiacol & 1.02 & 1.12 & 1.10 & 1.18 \\
\hline benzene vs veratrole & 1.00 & 1.06 & 1.06 & 1.12 \\
\hline toluene $v s p$-methylphenol & 1.00 & 1.58 & 1.58 & 1.07 \\
\hline resorcinol vs $p$-fluorophenol & 1.03 & 1.43 & 1.38 & 2.02 \\
\hline resorcinol vs $p$-chlorophenol & 1.12 & 1.34 & 1.20 & 1.21 \\
\hline resorcinol vs trifluoromethylbenzene & 2.13 & 2.49 & 1.17 & 1.55 \\
\hline resorcinol vs trichloromethylbenzene & 2.75 & 4.79 & 1.74 & 4.59 \\
\hline
\end{tabular}

Notes: $*$ - the uncertainties of the parameters were $5-7 \%$ 


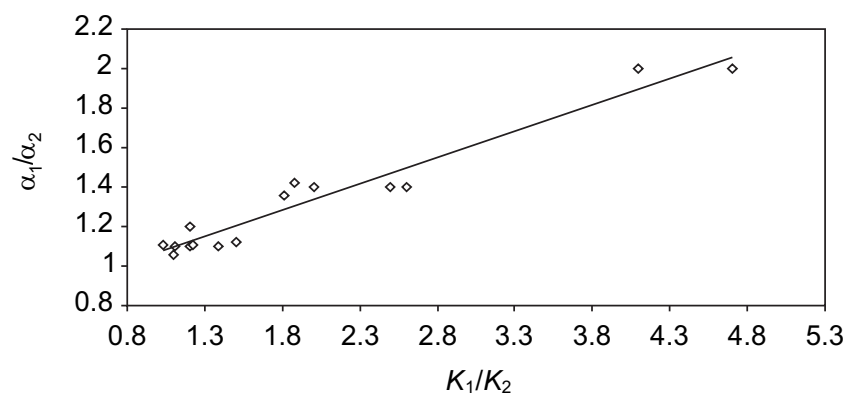

Fig. 6. Plots of the ratio of selectivity separation $\left(\alpha_{1} / \alpha_{0}\right)$ of the analytes $v s$ the ratio of the stability constants $\left(S=K_{1} / K_{2}\right)$ of their host-guest complexes with calix[4]arene $1\left(R^{2}=0.94\right)$

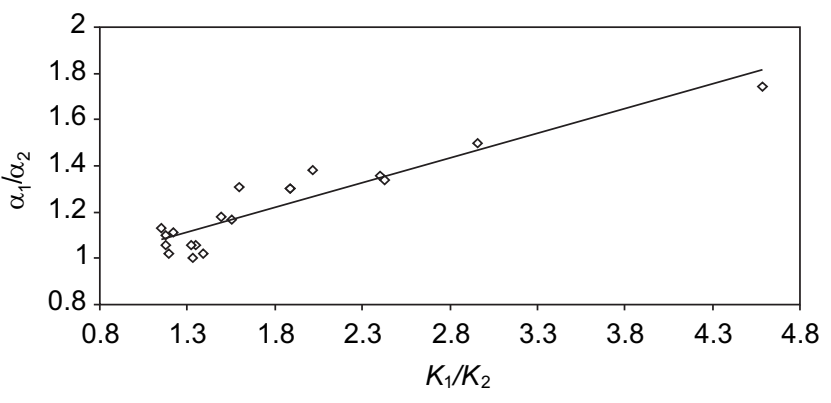

Fig. 7. Plots of the ratio of selectivity separation $\left(\alpha_{1} / \alpha_{0}\right)$ of the analytes $v s$ the ratio of the stability constants $\left(S=K_{1} / K_{2}\right)$ of their host-guest complexes with calix[8]arene $2\left(R^{2}=0.87\right)$

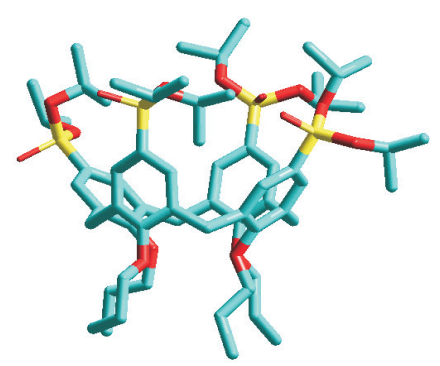

a

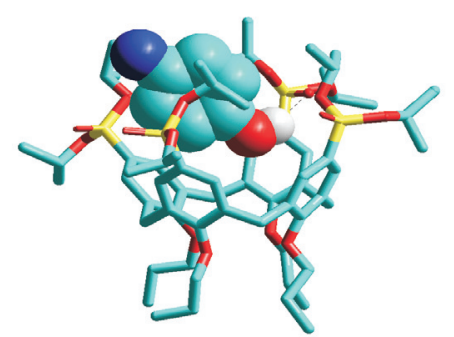

b

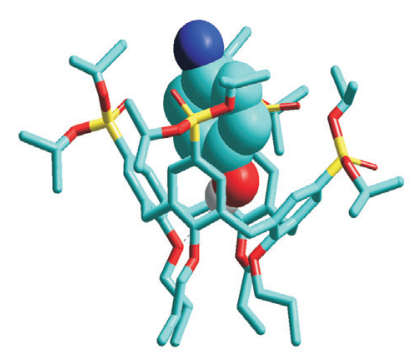

C

Fig. 8. The energy minimized molecular structures of calixarene 1 (a) and its complexes with $p$-aminophenol stabilized by the hydrogen bonds $\mathrm{Ar}-\mathrm{O}-\mathrm{H} \cdots \mathrm{O}=\mathrm{P}$ at the upper $\operatorname{rim}(\mathbf{b})$ and $\mathrm{Ar}-\mathrm{O}-\mathrm{H} \cdots \mathrm{O}(\mathrm{Pr})$ at the lower rim $(\mathbf{c})$ of the macrocycle

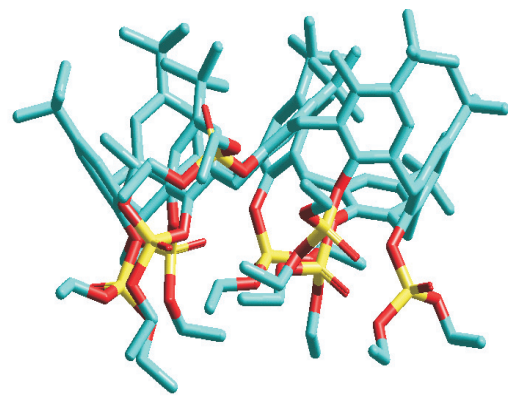

a

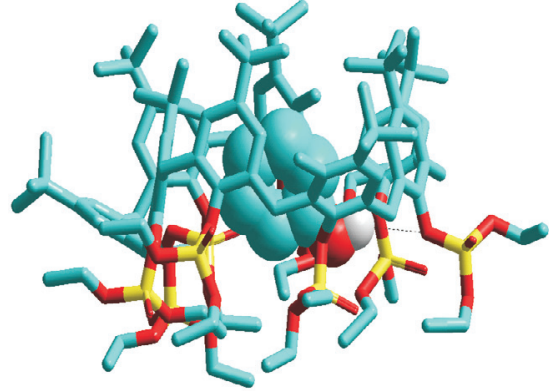

b

Fig. 9. The energy minimized molecular structure of calix[8]arene $\mathbf{2}$ (a) and its phenol complex (b)

\section{Molecular modelling}

The molecular modelling of calixarenes 1, 2 and their complexes with the analytes was carried out by the molecular mechanics MM+method, the force field (PM3) (Hyper Chem software package, version 8) [20]. The structures were calculated by the semi-empirical method. The RMS (standard deviation of the word root mean square) gradient was equal to $0.01 \mathrm{kcal} / \mathrm{A} \cdot \mathrm{mol}$.

\section{Conclusions}

The addition of phosphorylated derivatives of calix[4]arene and calix[8]arene to the acetonitrilewater mobile phase improves the selectivity of the chro- matographic separation of benzene analytes on the Separon SGX C18 stationary phase under HPLC. The improvement of the separation selectivity is explained by forming calixarene-analyte inclusion complexes with different sorption on the stationary phase compared to those of free analytes. The efficacy of such separation depends on the size of the calixarene backbone, as well as the nature, number and position of the substituents in the benzene analyte determining the structure and stability of the inclusion complexes.

Conflict of interests: authors have no conflict of interests to declare. 


\section{References}

1. Gutsche, C. D. Calixarenes: An introduction, 2 Ed.; Royal Society of Chemistry: Cambridge, 2008. https://doi.org/10.1039/9781847558190.

2. Asfari, Z.; Bohmer, V.; Harrowfield, J.; Vicens, J., Eds. Calixarenes 2001; Kluwer Academic Publishers: Dordrecht, 2001. https://doi.org/10.1007/0306-47522-7.

3. Böhmer, V. Calixarenes, macrocycles with (almost) unlimited possibilities. Angew. Chem., Int. Ed. Engl. 1995, 34 (7), 713-745. https://doi.org/10.1002/ anie.199507131.

4. Kalchenko, O. I.; Kalchenko, V. I. Chromatography in the chemistry of calixarenes; Naukowa dumka: Kyiv, 2013.

5. Kalchenko, O.; Lipkowski, J.; Kalchenko, V. Chromatography in supramolecular and analytical chemistry of calixarenes. Compr. Supramol. Chem. II, 2017, 239-261. https://doi.org/10.1016/B978-0-12-409547-2.13799-0.

6. Mandolini, L.; Ungaro, R., Eds. Calixarenes in action; Imperial College Press: Singapore, 2000. https://doi.org/10.1142/p168.

7. Cerenok, S.; Dutasta, J.-P.; Kalchenko, V. Phosphorus-containing chiral macrocycles. Curr. Org. Chem. 2006, 10 (18), 2307-2331. http://dx.doi.org/ $10.2174 / 138527206778992725$.

8. Kalchenko, O.; Poznański, J.; Marcinowicz, A.; Cherenok, S.; Solovyov, A.; Zielenkiewicz, W.; Kalchenko, V. Complexation of tetrapropoxycalix[4]arene with uracil and adenine derivatives in water-containing solution. J. Phys. Org. Chem. 2003, 16 (4), 246-252. https://doi.org/10.1002/poc.595.

9. Lugovskoy, E. V.; Gritsenko, P. G.; Koshel, T. A.; Koliesnik, I. O.; Cherenok, S. O.; Kalchenko, O. I.; Kalchenko, V. I.; Komisarenko, S. V. Calix[4]arene methylenebisphosphonic acids as inhibitors of fibrin polymerization. FEBS J. 2011,278 (8), 1244-1251. https://doi.org/10.1111/j.1742-4658.2011.08045.x.

10. Glennon, J. D.; Horne, E.; Hall, K.; Cocker, D.; Kuhn, A.; Harris, S. J.; McKervey, M. A. Silica-bonded calixarenes in chromatography: II. Chromatographic retention of metal ions and amino acid ester hydrochlorides. J. Chromatogr. A 1996, 731 (1), 47-55. https://doi.org/10.1016/00219673(95)01080-7.

11. Sokoließ, T.; Schönherr, J.; Menyes, U.; Roth, U.; Jira, T. Characterization of calixarene- and resorcinarene-bonded stationary phases: I. Hydrophobic interactions. J. Chromatogr. A 2003, 1021 (1), 71-82. https://doi.org/10.1016/j.chroma.2003.09.014.

12. Sokoließ, T.; Menyes, U.; Roth, U.; Jira, T. Separation of cis- and trans-isomers of thioxanthene and dibenz[b,e]oxepin derivatives on calixareneand resorcinarene-bonded high-performance liquid chromatography stationary phases. J. Chromatogr. A 2002, 948 (1), 309-319. https://doi. org/10.1016/S0021-9673(01)01317-6.

13. Śliwka-Kaszyńska, M. Calixarenes as stationary phases in high performance liquid chromatography. Crit. Rev. Anal. Chem. 2007 , 37 (3), $211-224$. https://doi.org/10.1080/10408340701244672.

14. Schneider, C.; Menyes, U.; Jira, T. Characterization of calixarene-bonded stationary phases. J. Sep. Sci. 2010, 33 (19), 2930-2942. https://doi.org/ 10.1002/jssc.201000281.

15. Hashem, H.; Ibrahim, A. E.; Elhenawee, M. Chromatographic analysis of some drugs employed in erectile dysfunction therapy: Qualitative and quantitative studies using calixarene stationary phase. J. Sep. Sci. 2014, 37 (20), 2814-2824. https://doi.org/10.1002/jssc.201400276.

16. Hashem, H. Chromatographic application on a calixarene stationary phase: A novel HPLC determination of flumethasone pivalate and salicylic acid in their binary mixture and ointment dosage form after two steps extraction. UK J. Pharm. Biosci. 2016, 4 (2), $70-76$.

17. Kalchenko, O. I.; Cherenok, S. O.; Solovyov, A. V.; Kalchenko, V. I. Influence of calixarenes on chromatographic separation of benzene or uracil derivatives. Chromatographia 2009, 70 (5), 717-721. https://doi.org/10.1365/s10337-009-1229-2.

18. Solovyov, A. V.; Cherenok, S. O.; Kalchenko, O. I.; Atamas, L. I.; Kazantseva, Z. I.; Koshets, I. A.; Tsymbal, I. F.; Kalchenko, V. I. Synthesis and complexation of amphiphilic calix[4]arene phosphonates with organic molecules in solutions and Langmuir-Blodgett films. J. Mol. Liq. 2011, 159 (2), 117-123. https://doi.org/10.1016/j.molliq.2010.12.007.

19. Kalchenko, O. I.; Lipkowski, J.; Kalchenko, V. I.; Vysotsky, M. A.; Markovsky, L. N. Effect of octakis(diethoxyphosphoryloxy)-tert-butyl-calix[8]arene in mobile phase on the reversed-phase retention behavior of aromatic compounds: host-guest complex formation and stability constants determination. J. Chromatogr. Sci. 1998, 36 (5), 269-273. https://doi.org/10.1093/chromsci/36.5.269.

20. HYPERCUBE, Inc. Product evaluation. http://www.hyper.com/Download/AllDownloads/tabid/470/Default.aspx (accessed Aug 1, 2020). 